\title{
Effect of essential oils and aqueous extracts of plants on in vitro rumen fermentation and methane production
}

\author{
Aarón Alejandro Molho-Ortiz | Atmir Romero-Pérez ${ }^{a}$ (D) | Efrén Ramírez-Bribiesca ${ }^{\text {iD }}$ |

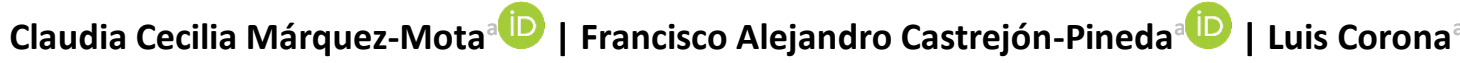

aDepartamento de Nutrición Animal y Bioquímica, Facultad de Medicina Veterinaria y Zootecnia, Universidad Nacional Autónoma de México, 04510, Mexico.

Colegio de Postgraduados, Montecillo, 56230, Mexico.

*Corresponding author: gochi@unam.mx

\begin{abstract}
The objective of this study was to evaluate in vitro rumen fermentation and methane production under the influence of two sources of phytochemicals: essential oils (EOs) and aqueous extracts (AEs). Treatments were set up in a completely randomized block design, with $4 \times 2+1$ factorial arrangement of four species, $\mathrm{S}$ (garlic, G; cinnamon, C; rosemary, R; eucalyptus; EU) $\times$ two types of presentation, P (essential oil, EO; aqueous extract, AE) and a basal diet, BD (50\% concentrate, $20 \%$ alfalfa and $30 \%$ corn silage). Rumen fermentation was evaluated using the in vitro gas production technique. All experimental units were incubated with $500 \mathrm{mg}$ of BD for 72 hours. Treatments were added at a single dose of $900 \mathrm{mg} / \mathrm{L}$ of rumen inoculum. Gas pressure was recorded at $0,2,4,6,8,10,14,18,24,30,36,42,48,60$ and $72 \mathrm{~h}$ postincubation. There was an interaction effect $(P \times S)$ between plant extract presentation $(P)$ and plant species $(S)$ for all variables. Treatments GEO, CEO, REO decreased volatile fatty acids ( $\mathrm{mmol} / 200 \mathrm{mg}$ ), microbial mass production ( $\mathrm{mg} / \mathrm{g}$ ), $\mathrm{CH}_{4}$ production $(\mathrm{mL} / \mathrm{g})$, in vitro dry matter digestibility $(P<0.05)$, and total gas production at 24 and $72 \mathrm{~h}$ post-incubation $(P<$ $0.05 ; \mathrm{mL} / \mathrm{g} \mathrm{DM}, \mathrm{mL} / \mathrm{g} \mathrm{OM})$. No differences $(P>0.05)$ were observed between AEs and BD. In conclusion, the use of EOs negatively affected rumen fermentation parameters and the production of $\mathrm{CH}_{4}$. Garlic and cinnamon EOs effectively reduced methane emissions; however, they also reduced in vitro dry matter digestibility.
\end{abstract}

Keywords: cinnamon, garlic, greenhouse gas, phytochemicals, sheep

\section{Introduction}

The world's population will reach 9.6 billion people in 2050, with twice the purchasing power for the consumption of meat and dairy products (FAO 2016), so it has been estimated that greenhouse gas (GHG) emissions from livestock activities will increase as the demand for these products increases (O'Mara 2011). The agriculture, forestry, and other land-use sectors contribute approximately $25 \%$ (10-12 Gt $\mathrm{CO}_{2}$ equivalent/year) of the net anthropogenic emissions of GHGs (IPCC 2014b), the most significant ones being carbon dioxide $\left(\mathrm{CO}_{2}\right)$, nitrous oxide, and methane $\left(\mathrm{CH}_{4}\right)$. Methane has a warming potential 21-28 times greater than $\mathrm{CO}_{2}$ (IPCC 2014a) and is released by enteric fermentation, slurry management, and rice crops; together, these add a total of 5-5.8 Gt CO $\mathrm{CO}_{2}$ equivalent/year (IPCC 2014b). Some studies estimate that the livestock supply chain contributes $14.5 \%$ of all human emissions (Gerber et al 2013). Methane formation during ruminal fermentation is considered a loss of energy of $2-12 \%$ of the gross energy intake (Kobayashi 2010 ). Multiple natural strategies have been investigated to reduce enteric methane production. Alternatives based on the use of natural compounds are attractive due to regulation in the use of antibiotics (European parliament 2003). Essential oils (EOs) (Cobellis et al 2016), tannins (Poornachandra et al 2019), and saponins (Jafari et al 2016) can modulate ruminal activity and, in some cases, increase animal productivity; however, their effectiveness on in vivo and in vitro experiments has not been consistent and conclusive (Patra and Saxena 2009), so there is a window of opportunity for research these substances, particularly EOs and plant extracts (Wencelová et al 2015). It has been shown that different effects could be observed according to the type of solvent used in the extraction; for example, plant extracts in ethanol, methanol, and water ( $T$. chebula, T. belerica, E. officinalis, and A. indica) all decreased in vitro dry matter digestibility (IVDMD). In contrast, only $T$. chebula methanol extract decreased $\mathrm{CH}_{4}$ production close to zero (Patra et al 2006a). Otherwise, garlic's aqueous extract $(\mathrm{AE})$ caused higher gas production in vitro. However, ethanol and methanol extracts of the same plant reduced gas and methane production (Patra et al 2006b), and AEs of olive leaves increased methanogenesis (Aggoun et al 2017). Meanwhile, Sirohi et al (2009) contrasted acetone, methanol, and water extracts of garlic and eucalyptus, finding a decrease in $\mathrm{CH}_{4}$ production in acetone and methanol garlic extracts, but an increase when it was extracted with water 
(2.61 mL/g DM higher than control). Moreover, eucalyptus acetone extract reduced methanogenesis $(37.34 \mathrm{~mL} / \mathrm{g} \mathrm{DM}$ lower than control), eucalyptus water extract, decreased $\mathrm{CH}_{4}$ $4.79 \mathrm{~mL} / \mathrm{g}$ DM compared to control (Sirohi et al 2009). Essential oils (CEO, GEO, and REO) have shown potential methane inhibiton (Cobellis et al 2016). It has also been concluded that there are differences in metabolites present in AEs and EOs (Salzer and Furia, 1977). We hypothesize that depending on the type of extraction, different secondary metabolites are obtained in the aqueous or oily extracts, and their effect on $\mathrm{CH}_{4}$ production will be different. The objective of this study was to evaluate the effects of AEs and EOs of garlic (A. sativum), cinnamon (C. verum), rosemary ( $R$. officinalis), and eucalyptus ( $E$. globulus) on ruminal fermentation and $\mathrm{CH}_{4}$ production, using the in vitro gas production technique.

\section{Materials and Methods}

The experimental protocol $\left(n^{\circ} 553\right)$ for the use of experimental animals (three rumen fistulated male ovine, 55 $\pm 0.5 \mathrm{~kg}$ ) as rumen liquid donors was approved by the Institutional Committee for the Care and Use of Experimental Animals, according to official animal care normativity (NOM062-ZOO-1999) (Diario Oficial de la Federación 2001). Experiments were carried out at the Center for Practical Teaching and Research in Animal Production and Health. Analysis of all samples (residual DM, gas samples, and rumen inoculum) was carried out in the Department of Animal Nutrition and Biochemistry of the Faculty of Veterinary Medicine and Animal Science of the National Autonomous University of Mexico.

\subsection{Experimental design and treatments}

Treatments were set up in a completely randomized block design, with $4 \times 2+1$ factorial arrangement of four species, S (Garlic, G; cinnamon, C; rosemary, R; eucalyptus; $\mathrm{EU}) \times$ two types of presentation, $\mathrm{P}$ (essential oil, EO; aqueous extract, $A E)$ and a basal diet, $B D$, consisting of $50 \%$ commercial concentrate (Purina ${ }^{\circledR}$, Ovina Engorda 15, México), $20 \%$ alfalfa and $30 \%$ corn silage on a dry matter (DM) basis. The basal diet was used as a control. The blocking criterion was incubation run (4), using four repetitions in the first, second, and third repetitions and two in the final ( $n=$ 14). All phytochemicals were added at a dose of $900 \mathrm{mg} / \mathrm{L}$ of rumen inoculum, as Joch et al (2017) reported.

\subsection{Phytochemicals}

Essential oils of garlic (GEO), cinnamon (CEO), rosemary (REO), eucalyptus (EEO), and the aqueous extract of cinnamon (CAE) were donated by the Rosa Helena Dueñas $^{\mathrm{TM}}$ laboratory. Aqueous extracts of eucalyptus (EAE) and rosemary (RAE) were isolated in our laboratory, using an extraction technique (Fernández-Agulló et al 2015) with a plant material/solvent ratio of 1:10. The solvents used were ethanol and distilled water in a 50:50 ratio. The extraction conditions were $50^{\circ} \mathrm{C}$, shaking speed at $200 \mathrm{rpm}$ for $90 \mathrm{~min}$ on a digital orbital shaker (Heathrow Scientific ${ }^{\circledR}$ HS120460, USA). After the extract was obtained, the plant material was vacuum filtered with a Büchner funnel and a Kitasato flask. The filtered extract was then evaporated to remove ethanol on a rotary evaporator (Büchi ${ }^{\mathrm{TM}}$ Rotavapor $^{\circledR}$ R-200, Switzerland) with the following conditions: $60^{\circ} \mathrm{C}, 70 \mathrm{rpm}$ for approximately $30 \mathrm{~min}$, until evaporation of half the initial volume. The aqueous garlic extract (GAE) was prepared from a dry garlic concentrate (ADEGERMEX ${ }^{\mathrm{TM}}$ laboratory). Garlic concentrate $(0.9 \mathrm{~g})$ was dissolved in $100 \mathrm{~mL}$ of water, heated at $50{ }^{\circ} \mathrm{C}$, and shaking speed was $200 \mathrm{rpm}$ for $30 \mathrm{~min}$ (Tocmo et al 2016).

\subsection{Chemical analysis}

The chemical composition of each ingredient in the BD (commercial sheep concentrate, alfalfa, and corn silage) was determined using different AOAC (2016) methods: The neutral detergent fiber (NDF) and acid detergent fiber (ADF) contents were also analyzed (Van Soest et al 1991). Organic matter (OM) was determined by subtracting the weight of ashes after ignition and reported as percentage. The proportion of each ingredient was used to calculate the chemical composition of the diet (Table 1).

\subsection{In vitro gas production technique}

Rumen fluid was collected through the rumen cannula from three male Pelibuey sheep ( $55 \pm 1 \mathrm{~kg}$, 1-year-old) fed a diet of the same composition as the BD and water ad libitum. Rumen fluid was collected in the morning before animals were fed, filtered to eight layers of cheesecloth, and preserved under anaerobic conditions and temperature $\left(39^{\circ} \mathrm{C}\right)$. Subsequently, rumen fluid was mixed with reduced and mineral solutions (Menke et al 1979) in a ratio of 1:9 v/v to obtain the rumen inoculum (Theodorou et al 1994). Previously, $500 \mathrm{mg}$ DM of BD (ground in a Model 4 Wiley $^{\circledR}$ mill, through a 1-mm screen) was placed in 125-mL amber glass bottles, used as experimental units. All phytochemicals were added at a dose of $900 \mathrm{mg} / \mathrm{L}$ of rumen inoculum (Joch et al 2017). Then, $90 \mu \mathrm{L}$ of each treatment was applied inside the amber glass bottles using a micropipette. Subsequently, $100 \mathrm{~mL}$ of rumen inoculum were added and continuously flushed with $\mathrm{CO}_{2}$ to maintain anaerobic conditions. Bottles with rumen inoculum and no substrate were also incubated as blanks to adjust gas production values. Bottles were hermetically sealed with rubber stoppers and aluminum caps and then placed in a water bath with lateral oscillation $(30 / \mathrm{min})$ at $39{ }^{\circ} \mathrm{C}$. Gas pressure $\left(\mathrm{kg} / \mathrm{cm}^{2}\right)$ was recorded at 0 , $2,4,6,8,10,14,18,24,30,36,42,48,60$ and 72 h postincubation, using a digital manometer (Traceable ${ }^{\circledR}$, Fisher Scientific, USA).

\subsection{Gas sampling and analysis}

The total gas in the headspace of the glass bottles was completely removed using a $60-\mathrm{mL}$ syringe with a needle. Produced gas was collected at 6, 12, 18, 24, 48, and $72 \mathrm{~h}$. Subsequently, the gas collected was rapidly injected into 
sealed flasks containing $38 \mathrm{~mL}$ of a saturated $\mathrm{NaCl}$ solution $\mathrm{pH} 2$ (350 g of $\mathrm{NaCl}, 5 \mathrm{~mL}$ of $0.1 \%$ methyl orange) (TorresSalado et al 2017). Gas samples were analyzed for $\mathrm{CH}_{4}$ by gas chromatography in an Autosystem XL Perkin Elmer ${ }^{\circledR}$ chromatograph equipped with an $\mathrm{HP} \mathrm{AL} / \mathrm{S}$ column (Agilent Technologies, part 1902P-S21; $15 \mathrm{~m} \times 0.53 \mathrm{~mm} \times 15 \mu \mathrm{m})$, and $\mathrm{N}_{2}$ carrier gas was injected at $6.5 \mathrm{~mL} / \mathrm{min}$ flow and 4 psi pressure. The oven temperature was set to $40{ }^{\circ} \mathrm{C}$ for $3 \mathrm{~min}$ with an increase of $20^{\circ} \mathrm{C} / \mathrm{min}$ until $175^{\circ} \mathrm{C}$ and held for $3 \mathrm{~min}$. The flow of $\mathrm{H}_{2}$ was $400 \mathrm{~mL} / \mathrm{min}$, and airflow was 40-45 $\mathrm{mL} / \mathrm{min}$. The injector temperature was $200{ }^{\circ} \mathrm{C}$, and an FID detector $\left(200^{\circ} \mathrm{C}\right)$ was used. Volume injection was $1 \mu \mathrm{l}$.

Table 1 Ingredients and chemical composition of the basal diet.

\begin{tabular}{lc}
\hline Item & $\%$ \\
\hline Ingredient & \\
\hline Corn silage & 30 \\
Alfalfa hay & 20 \\
${ }^{2}$ Commercial concentrate & 50 \\
\hline Chemical composition & \\
\hline Dry Matter & 99.3 \\
Crude protein & 12.4 \\
Ether extract & 4.4 \\
Organic matter & 90.8 \\
Crude fiber & 15.5 \\
NDF & 43.9 \\
ADF & 21.8 \\
NFE & 58.5 \\
TDN & 68.8 \\
${ }^{3} \mathrm{DE} \mathrm{(Kcal/kg)}$ & 3033.4 \\
${ }^{4} \mathrm{ME}(\mathrm{Kcal} / \mathrm{kg})$ & 2487.4 \\
${ }^{5} \mathrm{NEm} \mathrm{(Kcal/kg)}$ & 1595.5 \\
${ }^{6} \mathrm{NEg}(\mathrm{Kcal} / \mathrm{kg})$ & 996.6 \\
\hline
\end{tabular}

${ }^{1}$ Dry matter basis. ${ }^{2}$ Purina ${ }^{\circledR}$, Ovina Engorda 15 . AOAC methods: Dry matter (method 934.01), crude protein (method 2001.11) ether extract (method 920.39), ashes (method 942.05) crude fiber (method 962.09). NDF $=$ Neutral detergent fiber. $A D F=$ Acid detergent fiber. NFE = Nitrogen free extract. TDN = Total digestible nutrients. $\mathrm{DE}=$ Digestible energy. $\mathrm{ME}=$ Metabolizable energy, NEm = Net energy for maintenance. NEg = Net energy for growth . NFE was calculated as: $100-(\% \mathrm{CP}+\% \mathrm{EE}+\% \mathrm{CF}+\%$ Ashes $)$. TDN was calculated as: $\%$ TDN $=((\mathrm{CP} \times 0.75)+(\mathrm{EE} \times 0.9) \times 2.25+(\mathrm{CF} \times 0.5)+(\mathrm{NFE} \times$ 0.75)) ${ }^{3} \mathrm{DE},{ }^{4} \mathrm{ME},{ }^{5} \mathrm{NEm}$ and ${ }^{6} \mathrm{NEg}$ were estimated based on NRC (2001) following equations:

$\mathrm{DE}=\mathrm{TDN} *$ 4.409. $\mathrm{EM}=\mathrm{DE} \times 0.82 . \mathrm{NEm}=\left[(1.37 \times \mathrm{ME})-\left(0.138 \times \mathrm{ME}^{2}\right)+\right.$ $\left.\left(0.0105 \times \mathrm{ME}^{3}\right)\right]-1.12 . \mathrm{NEg}=\left[(1.42 \times \mathrm{ME})-\left(0.174 \times \mathrm{ME}^{2}\right)+\left(0.0122 \times \mathrm{ME}^{3}\right)\right]-$ 1.65

\section{6. $\mathrm{pH}$ and in vitro digestibility of dry matter}

After 72-h incubation, fermentation was stopped by placing the amber glass bottles in an ice bath. Rumen $\mathrm{pH}$ was then determined with a portable potentiometer $(\mathrm{pH}$ Tester model 30 Double Function ${ }^{\circledR}$ ). Residual DM was used to estimate the IVDMD as described by Theodorou et al (1994). Contents of all bottles were filtered individually using filter paper discs (Whatman No. 41), a Büchner funnel, and a vacuum pump. After filtering, the filter paper discs were placed in a forced-air oven at $55{ }^{\circ} \mathrm{C}$ for $48 \mathrm{~h}$ and weighed
(Ohaus-Explorer ${ }^{\circledast}$ model AX12478, México) to determine residual DM.

\subsection{Ruminal kinetics}

The gas pressure readings $\left(\mathrm{kg} / \mathrm{cm}^{2}\right)$ were transformed to gas volume (GasVol; $\mathrm{mL}$ ) with a linear regression equation:

GasVol = Pressure / 0.019; $R^{2}=0.988$

Data was adjusted with pressure values registered in the blanks; these were subtracted from the pressure readings of the treatments on each incubation time. After adjusting data, the gas volume and incubation time obtained from the previously linear regression equation were averaged and grouped to obtain cumulative gas volume per hour and total gas production at $24 \mathrm{~h}$ and $72 \mathrm{~h}(\mathrm{~mL} / \mathrm{g})$. Cumulative gas values were used to fit the model of France et al (1993).

\subsection{Estimation of volatile fatty acids (VFA) and production of microbial mass (MM)}

The VFA production (mmol/200 $\mathrm{mg}$ DM) was calculated using gas production (Gp), according to Getachew et al (2002), using the following equation:

VFA $(\mathrm{mmol} / 200 \mathrm{mg} \mathrm{DM})=0.0222 \mathrm{Gp}-0.00425$

The production of MM was calculated according to the methodology of Blümmel et al (1997), with modifications (Salem 2012), using the following equation:

$\mathrm{MM}(\mathrm{mg} / \mathrm{g} \mathrm{DM})=$ APS $(\mathrm{mg} \mathrm{DM})-(\mathrm{mL}$ gas $\times 2.2 \mathrm{mg} / \mathrm{mL})$

where APS = apparently degraded substrate and $2.2 \mathrm{mg} / \mathrm{mL}$ is a stoichiometric factor that expresses the mass $(\mathrm{mg})$ of $\mathrm{C}$, $\mathrm{H}$, and $\mathrm{O}$ required by the VFA associated with the production of $1 \mathrm{~mL}$ of gas.

\subsection{Statistical analysis}

The variables were analysed with the MIXED procedure of SAS. Treatment means were compared with a Tukey analysis, using the following contrasts: $\mathrm{EO}$ vs $\mathrm{AE}, \mathrm{BD}$ vs $E O$ and $B D$ vs $A E$, according to the following model (Cochran and Cox 1992):

Yijk $=\mu+\alpha i+\beta j+(\alpha \beta) i j+\gamma k+\varepsilon i j k$

In the model, Yijk is the response variable in the i-th species, the j-th presentation of extract, in the k-th repetition of the $\gamma$-th run, $\mu$ is the general mean, $\alpha i$ is the effect of the species at level $i, \beta j$ is the effect of the presentation of extract at level $j,(\alpha \beta)$ ij is the effect of the interaction species $x$ presentation of extract at level $\mathrm{ij}, \gamma \mathrm{k}$ is the block effect and हijk is the random error. Contrasts were considered significant when the $P$-value was $\leq 0.05$.

\section{Results}

\subsection{Fermentation parameters}

The interaction between phytochemicals presentation and species $(\mathrm{P} \times \mathrm{S})$ was significant $(P<0.001)$ for all fermentation parameters $(\mathrm{pH}$, IVDMD, VFA, and MM; Table 
2). Rumen $\mathrm{pH}$ (Table 2) was lower $(P<0.001)$ for CEO, GAE, and RAE concerning BD. Mean pH for GEO, EEO, REO, CAE, and $\mathrm{EAE}$ was no different $(P>0.05)$ from BD.

The VFA production (Table 2$)$ was lower $(P<0.001)$ for REO, GEO and CEO compared to BD $(P<0.001)$ by 13,22 and $47 \%$, respectively. Furthermore, CEO and GEO decreased $(P<$
0.001) VFA production compared to EEO, AE, and BD. The MM production was decreased $(P<0.001)$ by REO, GEO, and CEO (Table 2 ) by 11,19 , and $57 \%$, respectively, compared to BD. The lowest $(P<0.001)$ MM production was obtained with CEO, whose mean was $63 \%$ lower compared to EEO, which was similar $(P>0.05)$ to $\mathrm{AE}$ and BD.

Table 2 Effect of essential oils and aqueous extracts on fermentation parameters: $\mathrm{pH}$, in vitro dry matter digestibility, volatile fatty and microbial mass production.

\begin{tabular}{|c|c|c|c|c|c|}
\hline & Species & $\mathrm{pH}$ & $\begin{array}{l}\text { IVDMD } \\
\%^{72 h-1}\end{array}$ & $\begin{array}{c}\text { VFA } \\
(\mathrm{mmol} / 200 \mathrm{mg} \mathrm{DM})\end{array}$ & $\begin{array}{c}\mathrm{MM} \\
(\mathrm{mg} / \mathrm{g} \mathrm{DM})\end{array}$ \\
\hline \multirow{4}{*}{ Essential oils } & GEO & $6.55^{a b c}$ & $50.5^{c}$ & $2.95^{c}$ & $192.20^{c}$ \\
\hline & CEO & $6.41^{c}$ & $47.7^{c}$ & $1.99^{d}$ & $102.50^{d}$ \\
\hline & EEO & $6.51^{\mathrm{abc}}$ & $61.7^{\mathrm{b}}$ & $4.05^{a}$ & $278.23^{a}$ \\
\hline & REO & $6.66^{a}$ & $56.8^{\mathrm{bc}}$ & $3.28^{b c}$ & $211.95^{b c}$ \\
\hline \multirow{4}{*}{ Aqueous extracts } & GAE & $6.46^{\mathrm{bc}}$ & $70.6^{a}$ & $3.86^{a}$ & $241.31^{\mathrm{abc}}$ \\
\hline & CAE & $6.63^{\mathrm{ab}}$ & $68.1^{\mathrm{a}}$ & $3.90^{a}$ & $251.62^{\mathrm{ab}}$ \\
\hline & EAE & $6.53^{a b c}$ & $67.9^{a}$ & $3.97^{a}$ & $257.82^{\mathrm{ab}}$ \\
\hline & RAE & $6.46^{b c}$ & $68.4^{a}$ & $4.00^{\mathrm{a}}$ & $260.09^{a b}$ \\
\hline \multirow{2}{*}{ Control } & $\mathrm{BD}$ & $6.63^{a}$ & $69.2^{\mathrm{a}}$ & $3.79^{a b}$ & $237.62^{\mathrm{abc}}$ \\
\hline & SEM & 0.17 & 1.1 & 0.06 & 5.5 \\
\hline \multirow{7}{*}{ Contrasts } & Block & $<0.001$ & $<0.001$ & $<0.001$ & $<0.001$ \\
\hline & Presentation & 0.55 & $<0.001$ & $<0.001$ & $<0.001$ \\
\hline & Specie & 0.38 & $<0.001$ & $<0.001$ & $<0.001$ \\
\hline & $P \times S$ & $<0.001$ & $<0.001$ & $<0.001$ & $<0.001$ \\
\hline & EOs vs AEs & 0.59 & $<0.001$ & $<0.001$ & $<0.001$ \\
\hline & $\mathrm{BD}$ vs EOs & 0.01 & $<0.001$ & $<0.001$ & 0.002 \\
\hline & $\mathrm{BD}$ vs $\mathrm{AEs}$ & 0.006 & 0.71 & 0.26 & 0.26 \\
\hline
\end{tabular}

Abbreviations: IVDMD = in vitro dry matter digestibility; VFA =volatile fatty acids (mmol/200 mg DM); MM= microbial mass production (mg/g DM); Presentation = essential oil $(\mathrm{EO})$ or aqueous extract $(\mathrm{AE})$; Specie; garlic $(\mathrm{G})$; cinnamon $(\mathrm{C})$; eucalyptus $(\mathrm{E})$; rosemary $(\mathrm{R})$; $\mathrm{BD}=$ basal diet; $\mathrm{Block}=$ experimental block; $\mathrm{P} \times \mathrm{S}=$ interaction between presentation and species. Contrasts: EOs vs $A E s=$ essential oils vs aqueous extracts; $B D$ vs $E O s=$ basal diet vs essential oils; $B D$ vs $A E s=$ basal diet vs aqueous extracts.

\subsection{In vitro dry matter digestibility}

All EOs decreased $(P<0.001)$ IVDMD compared to all AEs and BD (21.2\% and $21.7 \%$, respectively). Treatments GEO and CEO decreased IVDMD $(P<0.001)$ by $18 \%$ and $22 \%$ compared to EEO and by $27 \%$ and $31 \%$ concerning BD.

\subsection{Total gas and $\mathrm{CH}_{4}$ production}

Total gas and $\mathrm{CH}_{4}$ were expressed as $\mathrm{mL} / \mathrm{g}$ of $\mathrm{DM}, \mathrm{OM}$, and dry-matter digestibility (DMD; Table 3). Interaction between phytochemical presentation and species $(\mathrm{P} \times \mathrm{S})$ was found for all total gas and $\mathrm{CH}_{4}$ variables (Table 3; $P<0.001$ ).

Inclusion of REO, GEO, and CEO decreased (Table 3; $P$ $<0.001)$ the total gas production at $24 \mathrm{~h}$ and $72 \mathrm{~h}(\mathrm{~mL} / \mathrm{g}$ of $\mathrm{DM}$ and $\mathrm{mL} / \mathrm{g}$ of OM) when compared to BD (13\%, $22 \%$, and $47 \%$ at $24 \mathrm{~h}$ and $14 \%, 19 \%$ and $40 \%$ at $72 \mathrm{~h}$, respectively). Addition of GEO and CEO decreased (Table 3; $P<0.001$ ) the methane production ( $\mathrm{mL} / \mathrm{g} \mathrm{DMD}^{72 \mathrm{~h}}$ ) when compared to EEO, REO, $A E$, and $B D$ by $64.7 \%$ on average.

As observed in Figure 1, GEO, CEO, and REO showed lower cumulative gas production than the other treatments. Cumulative gas production for AEs did not differ from that of BD.

\section{Discussion}

\subsection{Fermentation parameters}

Their chemical nature can explain the inhibitory effect on rumen fermentation caused by EOs: a complex mixture of secondary plant metabolites with a highly variable composition. Their action mechanism against rumen microorganisms is still poorly understood (Cobellis et al 2016). However, it is speculated their mechanism involves membrane disruption of microorganisms (Griffin et al 1999). Decreases in $\mathrm{pH}$ are often associated with reductions in gas production, DM disappearance, and total VFA concentration (Fondevila and Pérez-Espés 2008). Negligible changes in $\mathrm{pH}$ due to GEO (Mateos et al 2013), REO (Castillejos et al 2008), and EEO (Cobellis et al 2016) have previously been reported. Decreases of $\mathrm{pH}$ were previously observed for $\mathrm{CEO}$ in vivo (Chaves et al 2008) and in vitro (Amin et al 2021). However, decreases are often related to VFA increases, not observed in the present study. Decreases on $\mathrm{pH}$ are also related to incubation times longer than 24 hours and characteristics of the in vitro technique, like lack of end-products removal (Williams et al 2010). To our knowledge, the effect of GAE on ruminal $\mathrm{pH}$ has not been reported, but the presence of highly 
degradable carbohydrates can lower $\mathrm{pH}$ (Hoover, 1986). The detrimental effects on rumen microbial fermentation in the present study (decrease in VFA production) when GEO, CEO, and REO were used have been previously reported (Doreau et al 2017). Macheboeuf et al (2008) used cinnamaldehyde (main active compound in CEO) and GEO at $5 \mathrm{mM} / \mathrm{L}$ in a 25:75 F/C diet. Reductions up to $60 \%$ of VFA production were observed by the CEO.

Table 3 Effect of essential oils and aqueous extracts on gas production parameters: Total gas production and $\mathrm{CH}_{4}$ production.

\begin{tabular}{|c|c|c|c|c|c|c|c|c|c|}
\hline & \multirow[t]{2}{*}{ Species } & \multicolumn{5}{|c|}{ Total gas } & \multicolumn{3}{|c|}{$\mathrm{CH}_{4}$} \\
\hline & & $\left(\mathrm{mL} / \mathrm{g} \mathrm{DM}^{24 \mathrm{~h}}\right)$ & $\left(\mathrm{mL} / \mathrm{g} \mathrm{DM}^{72 \mathrm{~h}}\right)$ & $\left(\mathrm{mL} / \mathrm{g} \mathrm{OM}^{24 \mathrm{~h}}\right)$ & $\left(\mathrm{mL} / \mathrm{g} \mathrm{OM}^{72 \mathrm{~h}}\right)$ & $\left(\mathrm{mL} / \mathrm{g} D M D^{72} \mathrm{~h}\right)$ & $\left(\mathrm{mL} / \mathrm{g} \mathrm{DM}^{72 \mathrm{~h}}\right)$ & $\left(\mathrm{mL} / \mathrm{g} \mathrm{OM}^{72 \mathrm{~h}}\right)$ & $\left(\mathrm{mL} / \mathrm{g} \mathrm{DMD} \mathrm{D}^{72 \mathrm{~h}}\right)$ \\
\hline \multirow{4}{*}{$\begin{array}{l}\text { Essential } \\
\text { oils }\end{array}$} & GEO & $333.09^{b}$ & $485.47^{b}$ & $325.35^{b}$ & $474.21^{b}$ & $1932.1^{\mathrm{a}}$ & $4.60^{c}$ & $4.49^{c}$ & $22.71^{b}$ \\
\hline & CEO & $224.92^{c}$ & $361.87^{c}$ & $219.89^{c}$ & $353.77^{c}$ & $1770.6^{\mathrm{ab}}$ & $7.02^{c}$ & $6.86^{c}$ & $33.37^{b}$ \\
\hline & EEO & $456.44^{a}$ & $637.65^{a}$ & $443.54^{a}$ & $619.63^{a}$ & $2083.6^{a}$ & $28.22^{\mathrm{a}}$ & $27.42^{\mathrm{a}}$ & $93.53^{a}$ \\
\hline & REO & $370.03^{b}$ & $521.22^{\mathrm{b}}$ & $360.42^{b}$ & $507.66^{b}$ & $1848.3^{\mathrm{a}}$ & $21.31^{b}$ & $20.76^{b}$ & $75.36^{a}$ \\
\hline \multirow{4}{*}{$\begin{array}{l}\text { Aqueous } \\
\text { extracts }\end{array}$} & GAE & $434.72^{\mathrm{a}}$ & $622.11^{a}$ & $420.62^{a}$ & $601.94^{a}$ & $1508.7^{b}$ & $27.65^{a}$ & $26.76^{a}$ & $74.44^{a}$ \\
\hline & CAE & $440.72^{\mathrm{a}}$ & $632.19^{a}$ & $426.94^{a}$ & $612.42^{\mathrm{a}}$ & $1861.9^{a}$ & $23.09^{a b}$ & $22.38^{a b}$ & $68.78^{a}$ \\
\hline & $\mathrm{EAE}$ & $447.31^{\mathrm{a}}$ & $640.77^{a}$ & $433.38^{a}$ & $620.81^{a}$ & $1900.4^{\mathrm{a}}$ & $28.97^{a}$ & $28.07^{a}$ & $83.99^{a}$ \\
\hline & RAE & $451.21^{\mathrm{a}}$ & $645.28^{\mathrm{a}}$ & $437.03^{a}$ & $625.00^{\mathrm{a}}$ & $1893.5^{\mathrm{a}}$ & $27.79^{a}$ & $26.92^{\mathrm{a}}$ & $81.51^{\mathrm{a}}$ \\
\hline \multirow[t]{2}{*}{ Control } & $B D$ & $427.43^{a}$ & $603.78^{a}$ & $413.84^{a}$ & $584.61^{a}$ & $1773.7^{a b}$ & $26.18^{a b}$ & $25.35^{\mathrm{ab}}$ & $77.99^{a}$ \\
\hline & SEM & 7.77 & 7.680 & 7.490 & 7.506 & 33.667 & 6.08 & 5.91 & 25.11 \\
\hline \multirow[t]{7}{*}{ Contrasts } & Block & $<0.001$ & $<0.001$ & $<0.001$ & $<0.001$ & $<0.001$ & $<0.001$ & $<0.001$ & 0.005 \\
\hline & Presentation & $<0.001$ & $<0.001$ & $<0.001$ & $<0.001$ & 0.708 & $<0.001$ & $<0.001$ & $<0.001$ \\
\hline & Specie & $<0.001$ & $<0.001$ & $<0.001$ & $<0.001$ & $<0.001$ & $<0.001$ & $<0.001$ & $<0.001$ \\
\hline & $P \times S$ & $<0.001$ & $<0.001$ & $<0.001$ & $<0.001$ & $<0.001$ & $<0.001$ & $<0.001$ & $<0.001$ \\
\hline & EOs vs AEs & $<0.001$ & $<0.001$ & $<0.001$ & $<0.001$ & 0.797 & $<0.001$ & $<0.001$ & $<0.001$ \\
\hline & $\mathrm{BD}$ vs EOs & $<0.001$ & $<0.001$ & $<0.001$ & $<0.001$ & 0.403 & $<0.001$ & $<0.001$ & $<0.001$ \\
\hline & $\mathrm{BD}$ vs AEs & 0.278 & 0.099 & 0.279 & 0.101 & 0.318 & 0.639 & 0.639 & 0.895 \\
\hline
\end{tabular}

Abbreviations: Total gas = total gas production at 24 and $72 \mathrm{~h}(\mathrm{~mL} / \mathrm{g}) ; \mathrm{DM}=$ dry matter; $\mathrm{OM}=$ organic matter; DMD= dry matter digestibility; Presentation = essential oil $(E O)$ or aqueous extract $(A E)$; Specie = garlic $(G)$, cinnamon $(C)$, eucalyptus $(E)$, rosemary $(R) ; B D=$ basal diet; $B l o c k=$ experimental block; $P \times S=$ interaction between presentation and species; Contrasts: EOs vs AEs = essential oils vs aqueous extracts; $B D$ vs EOs = basal diet vs essential oils; $B D$ vs $A E s=$ basal diet vs aqueous extracts.

Additionally, GEO decreased acetate production by $15 \%$ after $24 \mathrm{~h}$. In the present study REO; CEO and GEO decreased gas production; however, gas production does not consider the quantity of substrate converted in microbial biomass, so gas measurement can't be considered an estimate of apparent rumen digestibility (Blümmel and $\varnothing$ rskov, 1993). A positive correlation between gas production and IVDMD has been previously reported (Apori et al 1998). Moreover, a positive correlation between gas production and VFA production has been reported with high $R^{2}$ values $\left(R^{2}=\right.$ 0.94; $\mathrm{n}=94 ; P<0.001$ ) (Getachew et al 2002), which might explain reduction of VFA production observed. Gas production is an indicator of quantitative VFA production, since digested substrate is partitioned among VFA gas and microbial biomass (Getachew et al 2002). This approach has also been used and validated in different publications (Amanzougarene and Fondevila, 2020). However, gas production does not reflect the substrate utilized for microbial growth (Getachew et al 2004). As established by $\emptyset$ rskov (1994), MM production is limited to the number of units of carbohydrate fermented; moreover, it has been established that microbial biomass can be substantially altered by two means, bacterial lysis and turnover of protein within the rumen. In the present study, decreases in MM production caused by REO, GEO, and CEO could be explained because of the non-specific antibacterial properties of these compounds. The relationship between in vitro gas production and microbial biomass was established by Blümmel et al (1997), which found a significant negative relationship between gas produced and microbial biomass $\left(R^{2}=0.67\right)$. This methodology has been used previously to estimate microbial mass (Sahli et al 2018).

\subsection{In vitro dry matter digestibility}

In the present work, IVDMD was decreased $(P<0.001)$ for GEO CEO, EEO, and REO treatments. These results are expected as previous studies observed similar decreases when high doses of essential oils were used. Foskolos et al (2015) evaluated propyl-propane thiosulfinate (one of the active compounds on GEO) on continuous culture fermentators, it reduced $33 \%$ true organic matter digestibility when a high dose was used ( $300 \mathrm{mg} / \mathrm{L}$ vs. $30 \mathrm{mg} / \mathrm{L}$ ). Similarly, 
Cobellis et al (2016) used $1.125 \mathrm{mg} / \mathrm{L}$ of REO, EEO, and CEO and observed a decrease in IVDMD. Righi et al (2017) evaluated different essential oils (cinnamon, clove, thyme, oregano, carvacrol) and their active compounds on different feedstuffs (soybean meal, maize meal, lucerne hay, and a total mixed ration) on in vitro rumen fermentation. Interestingly EOs have different effects depending on the fermented substrate; for example, the addition of most EOs depressed DMD of soybean meal. Adverse effects of some EOs on feed digestion could be a consequence of their broad and non-specific antimicrobial activity (Cobellis et al 2016).

The antimicrobial activity of garlic has been attributed to its organosulfur compounds, particularly to allicin (Ankri and Mirelman 1999). Intact garlic bulbs contain the sulphur compounds S-alkenyl-L-cysteine sulfoxide and S-allylcysteine sulfoxide, which are present at between 1 and $5 \%$ of the dry weight of the plant (Patra 2012). When cells are damaged, the enzyme allinase releases and converts these compounds into other volatile and reactive components called thiosulfates, with allicin as the most abundant compound (Patra and Yu 2012a). Although, pure allicin is a volatile compound that is difficult to mix in aqueous solution and is reactive, turns quickly to other compounds under different conditions (Cardozo and Kamel 2008; Lawson and Gardner 2005). Cinnamon's most active compound is cinnamaldehyde, present at $60-75 \%$ in the EO, together with $4-10 \%$ of phenols, mainly eugenol and other hydrocarbons (Gopu et al 2008). The bioactive compounds of rosemary are more complex; they could contain in their leaves a cocktail of phenolic compounds and di-terpenes (carnasol, carnosic acid, rosmanol, epirsonmanol, isorosmanol, methyl carnosate and rosmarinic acid), and their activity as rumen modifiers and antioxidant compounds has been well documented (Cobellis et al 2015). Also, it has been observed that major components of REO (such as monoterpenes $\alpha$ pinene, $\beta$-pinene, camphene, 1,8-cineol, camphor, borneol, bornyl acetate and verbenone) are known for their antimicrobial properties against gram-positive and gramnegative bacteria (Jiang et al 2011). The presence of a phenolic moiety and the position of a hydroxyl group in the phenolic structure of the EO (e.g., EOs containing thymol or eugenol) can influence the antimicrobial potency of the EO (Ultee et al 2002).

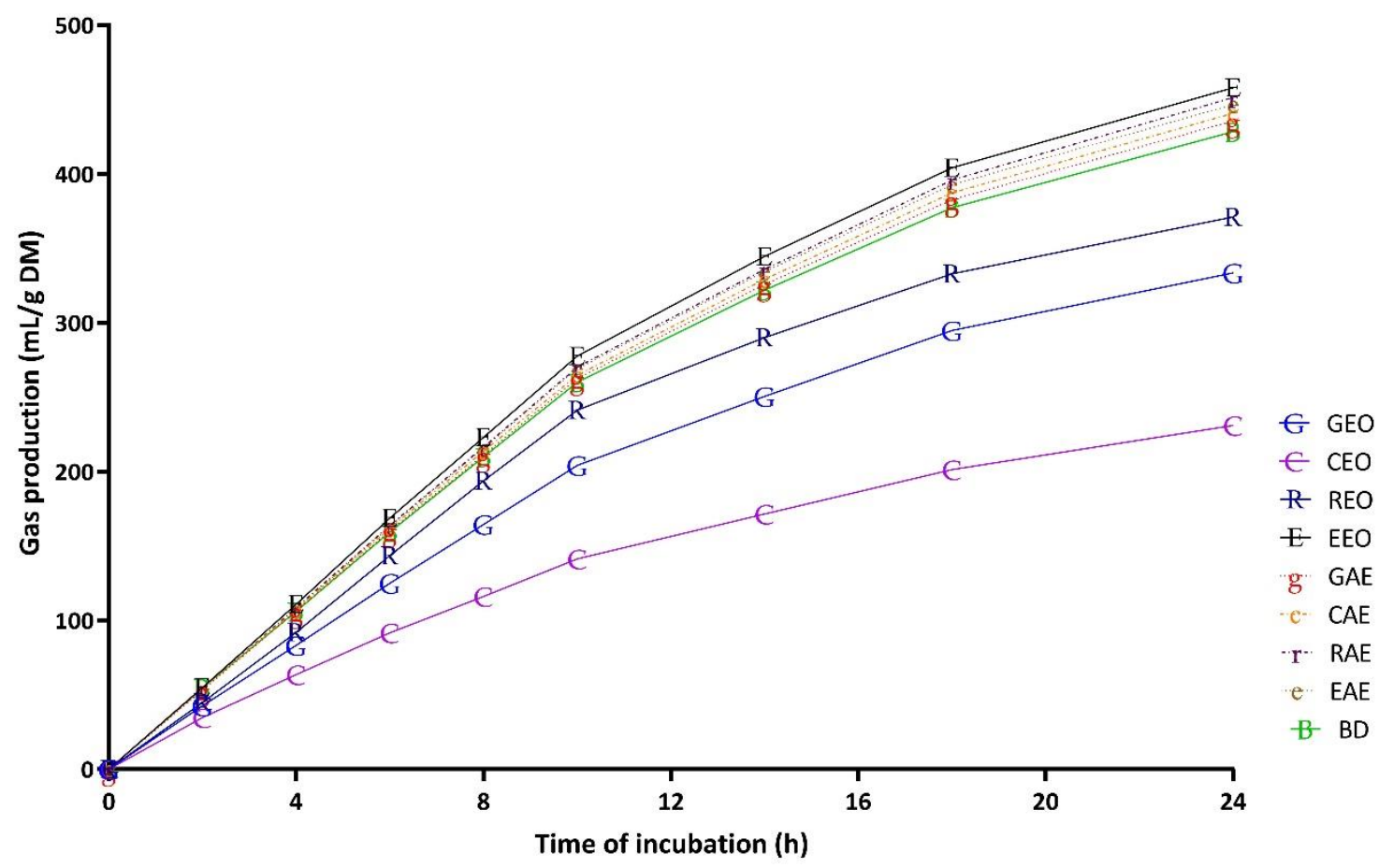

Figure 1 Effect of essential oils and aqueous extracts on cumulative gas volume kinetics. Abbreviations: First letter corresponds to Specie = garlic $(G)$, cinnamon $(C)$, eucalyptus $(E)$, rosemary $(R)$; second and third letter correspond to Presentation = essential oil $(E O)$ or aqueous extract $(A E)$. $B D=$ basal diet. Curves were fitted from the model of France et al ( 1993).

\subsection{Total gas and methane production}

In the present study, total gas was reduced $(P<0.001)$ by GEO, CEO, and REO. This is a response of the antibacterial properties EOs and has been previously reported. JahaniAzizabadi et al (2011) evaluated several EOs in a high-forage diet ( $80 \%$ alfalfa and $20 \%$ concentrate) where GEO was the most potent compound in reducing total gas and $\mathrm{CH}_{4}$ production. Patra and $\mathrm{Yu}$ (2015) evaluated different phytochemicals, including GEO, nitrate, and saponin $(Q$. saponaria), and their combinations in two types of diet: 70:30 and 30:70 F/C. Treatment GEO reduced total gas production concerning control treatment in a high-concentrate diet; methane was decreased by GEO in both diets. Doreau et al (2017) conducted an in vitro trial using $8 \mathrm{mg}$ of GEO in a 30:70 $\mathrm{F} / \mathrm{C}$ diet and found no differences in total gas production after 
$5 \mathrm{~h}$ of incubation but a reduction in total gas production at 24 $\mathrm{h}$ of incubation. The reduction in total gas and $\mathrm{CH}_{4}$ production by EOs indicates that these compounds could affect the fermentation of $\mathrm{OM}$ at 24 and $72 \mathrm{~h}$. Additives included at higher doses exhibit more biological activity and tend to decrease gas production at digestibility expenses. In the present study, REO decreased $(P<0.001)$ total gas $(\mathrm{mL} / \mathrm{g} \mathrm{DM}$, $\mathrm{mL} / \mathrm{g} \mathrm{OM}$ ), which is comparable to previously published data by O'Grady et al (2006), where in vitro fermentation trials were conducted in the presence of barley grain $(1 \mathrm{~g})$ as substrate. Using a low dose of REO $(0.1 \mathrm{~g})$ decreased gas production relative to the control treatment, indicating that fermentation and gas production were inhibited. A decrease in total gas was registered for CEO and REO and a decrease in IVDMD for CEO, REO, and EEO. These findings correspond with previous study by Cobellis et al (2016), who showed that EOs containing compounds such as cinnamaldehyde, present in CEO, have stronger antimicrobial activity than those that contain monoterpenes and phenols, for example, EEO and REO. Adverse effects of EOs on feed digestibility could also be a consequence of their non-specific antimicrobial activity.

Suppressing $\mathrm{CH}_{4}$ production without the negative effects on digestibility or fermentation is challenging. An ideal feed additive should improve rumen fermentation characteristics without adversely affecting feed intake or digestibility (Cobellis et al 2016), which might be possible with the optimal dose of compounds, specific action against methanogens, and specific substrate characteristics. The most effective treatment to reduce $\mathrm{CH}_{4}$ emission in the present study was GEO, which has already been reported as a potential modifier of rumen methanogenic communities. Ferme et al (2004) identified in GEO a particular compound, diallyl disulfide, which was the first plant extract to act selectively against methanogens and protozoa (Anassori et al 2011). It has been suggested that the organosulfur compounds found in GEO can directly inhibit rumen methanogenic archaea, inhibiting the enzyme 3-hydroxy-3methyl-glutaryl coenzyme A (HMG-CoA) reductase (Busquet et al., 2005; Patra and Saxena, 2010). As a result, the synthesis of the isoprenoid unit is inhibited, the Archaea membrane becomes unstable, and the cells die (Roy et al 2014).

In a similar manner to the present study, Patra et al (2006b) evaluated aqueous, ethanolic, and methanolic extracts of garlic, fennel ( $F$. vulgare), clove (S. aromaticum), onion (A. cepa) and ginger (Z. officinalis) in a 50:50 F/C diet. Their results suggested that $A E s$ were not effective in reducing methane production, indicating that antimethanogenic factors are extracted only into alcohol and methanol. Methanolic extractions were more effective in reducing $\mathrm{CH}_{4}$ production (65-83\% inhibition) than ethanolic extracts (26-52\% inhibition). Due to the volatile nature of the compounds present in EOs, those that are extracted with solvents or at low temperatures may have a higher bioactivity than those extracted with steam or water (Hart et al 2008). Another in vitro study conducted by the same research group (Patra et al 2009) suggested that the bioactive compounds present in garlic were more soluble in organic solvents such as ethanol and methanol, making GAE less effective than GEO in reducing the production of methane.

The positive effects of GEO and CEO in the reduction of $\mathrm{CH}_{4}$ production come with negative effects on several fermentation variables (total gas, IVDMD, VFA, and MM). Therefore, it is important to determine proper doses, where the addition of the phytochemical allows a decrease in $\mathrm{CH}_{4}$ without inhibiting ruminal fermentation. A suitable alternative product is one that reduces $\mathrm{CH}_{4}$ but not negatively affect other variables. The latter was not found in this research. However, contrary to our results, some authors reported positive effects (Yang et al 2007) or no effects (Meyer et al 2009) on feed intake or rumen feed degradability. As previously discussed, this depends on EOs composition, extraction method, diet composition, and selected dose. Several experiments have been conducted to determine suitable doses. Based on previous in vitro studies (Jahani-Azizabadi et al 2011; Patra and Yu 2012a), it appears that effective concentrations of GEO range from 300 to 500 $\mathrm{mg} / \mathrm{L}$. However, lower doses (135 $\mathrm{mg} / \mathrm{g}$ of the substrate) could also reduce $\mathrm{CH}_{4}$ production (up to $20 \%$ ), with no effect on gas production and marginal reductions in IVDMD (GarcíaGonzález et al 2008). Recently, Dey et al (2021) observed that a low dose of GEO (33.33 $\mu \mathrm{L} / \mathrm{L})$ in an in vitro trial with buffalo rumen fluid could reduce $\mathrm{CH}_{4}$ production by $38.35 \%$ without impairing feed digestion. Besides that, the four major components of garlic were tested individually, evaluating their effect on in vitro methanogenesis. It was then understood that only garlic oil, diallyl disulfide, and allyl mercaptan could inhibit $\mathrm{CH}_{4}$ emission.

In contrast, allicin was ineffective (Kamel et al 2008). It also has been demonstrated that the effect of the inclusion of garlic oil on in vitro methane and VFA production is dietand dose-dependent (Kamel et al 2009). On the other hand, the use of a higher dose $(1.125 \mathrm{~mL} / \mathrm{L}$ culture $)$ of CEO almost reduced to zero the production of $\mathrm{CH}_{4}$ in a trial where it was used individually, and by $37.7-78.5 \%$ when it was combined with other sources of EO, such as oregano, rosemary and eucalyptus leaves (Cobellis et al 2016). It is challenging to escalate doses from in vitro to in vivo trials because sometimes the functional levels of phytochemicals in vitro experiments are too high to be achieved in practice (Sharma and McNeill, 2009). However, some experiments have used doses from $1 \mathrm{~g} \mathrm{CEO/cow/d} \mathrm{(Benchaar} \mathrm{et} \mathrm{al} \mathrm{2008)} \mathrm{to} 5 \mathrm{~g}$ GEO/cow/d (Yang et al 2007), increasing true ruminal digestibility $(6.5 \%)$ and milk fat $(0.26 \%$, or $104 \mathrm{~g} / \mathrm{d})$ with the use of higher doses. Unfortunately, commercial EOs are expensive, so their beneficial effects on animal welfare and performance should be demonstrated before actual use in farms (Cobellis et al 2016).

Moreover, many aspects are still unknown, such as the synergistic and/or antagonistic interaction among EOs active compounds, such as trials that evaluated CEO and GEO combinations in small doses $(300 \mathrm{mg} / \mathrm{cow} / \mathrm{d}$ ) (Blanch et al 2016) decreased $\mathrm{CH}_{4}$ production. In contrast, a combination of different micro-encapsulated EOs had no effect (Alemu et 
al 2019). A meta-analysis conducted by Ungerfeld (2018) showed no association between methanogenesis inhibition and improvement in ruminants productivity. Further investigation might be necessary to understand the conditions under which methane mitigation and animal productivity enhancement can be achieved.

\section{Conclusions}

Overall, the use of garlic, cinnamon, and rosemary EOs negatively affected ruminal fermentation. Garlic and cinnamon EOs decreased methane production by $64.7 \%$ on average when compared to the other treatments. These three species are apparently better rumen modulators than eucalyptus. However, digestibility was also reduced; therefore, dose adjustment and in vivo studies have to be evaluated. On the other hand, AEs of all species showed negligible effects on ruminal fermentation, suggesting that water extraction methods may be inappropriate to obtain those secondary compounds present in the different species that impact rumen fermentation parameters, such as gas and methane production.

\section{Conflict of Interest}

The authors declare that there is no conflict of interest.

\section{Funding}

This research was partially funded by Universidad Nacional Autónoma de México, on project PAPIIT-DGAPA-UNAM(Projects IN226216 and IT202120).

\section{References}

Aggoun M, Boussaada A, Rabah A, Serine A, Malika B (2017) Effect of natural bioflavonoid on in vitro ruminal microbiota activity in sheep rumen liquor. Journal of bioscience and Biotechnology 6:31-35.

Alemu AW, Romero-Pérez A, Araujo RC, Beauchemin KA (2019) Effect of encapsulated nitrate and microencapsulated blend of essential oils on growth performance and methane emissions from beef steers fed backgrounding diets. Animals 9:1-19. doi: 10.3390/ani9010021.

Amanzougarene Z, Fondevila M (2020) Fitting of the in vitro gas production technique to the study of high concentrate diets. Animals 10:1910-1935. doi: 10.3390/ani10101935.

Amin N, Tagliapietra F, Arango S, Guzzo N, Bailoni L (2021) Free and microencapsulated essential oils incubated in vitro: ruminal stability and fermentation parameters. Animals 11:180. doi: 10.3390/ani11010180.

Anassori E, Dalir-Naghadeh B, Pirmohammadi R, Taghizadeh A, Asri-Rezaei S, Maham M, Farahmand-Azar S, Farhoomand P (2011) Garlic: a potential alternative for monensin as a rumen modifier. Livestock Science 142:276287. doi: 10.1016/j.livsci.2011.08.003.

Ankri S, Mirelman D (1999) Antimicrobial properties of allicin from garlic. Microbes and infection 1: 125-129. doi: 10.1016/S1286-4579(99)80003-3.

AOAC (2016) AOAC official methods of analysis. Assoc. Off. Agric. Chem. Washington, D.C. 20th, 136-138.

Apori SO, Castro FB, Shand WJ, Ørskov ER (1998) Chemical composition, in sacco degradation and in vitro gas production of some ghanaian browse plants. Animal Feed Science Technology 76:129-137. doi: 10.1016/S03778401(98)00205-3.

Benchaar C, McAllister TA, Chouinard PY (2008) Digestion, ruminal fermentation, ciliate protozoal populations, and milk production from dairy cows fed cinnamaldehyde, quebracho condensed tannin, or Yucca schidigera saponin extracts. Journal of Dairy Science 91:4765-4777. doi 10.3168/jds.2008-1338.

Blanch M, Carro MD, Ranilla MJ, Viso A, Vázquez-Añón M, Bach A (2016) Influence of a mixture of cinnamaldehyde and garlic oil on rumen fermentation, feeding behavior and performance of lactating dairy cows. Animal Feed Science abd Technology 219:313-323. doi: 10.1016/j.anifeedsci.2016.07.002.

Blümmel M, Ørskov ER (1993) Comparison of in vitro gas production and nylon bag degradability of roughages in predicting feed intake in cattle. Animal Feed Science and Technology 40:109-119. doi: 10.1016/03778401(93)90150-I.

Blümmel M, Steinga $\beta$ H, Becker K (1997) The relationship between in vitro gas production, in vitro microbial biomass yield and $\mathrm{N}$ incorporation and its implications for the prediction of voluntary feed intake of roughages. British Journal of Nutrition 77:911-921. doi:10.1079/BJN19970089.

Busquet M, Calsamiglia S, Ferret A, Carro MD, Kamel C (2005) Effect of garlic oil and four of its compounds on rumen microbial fermentation. Journal of Dairy Science 88:4393-4404. doi: 10.3168/jds.S0022-0302(05)73126-X.

Cardozo PW, Kamel C (2008) Plant extract as rumen modifiers. International Dairy Topics. Volume 7:7-9.

Castillejos L, Calsamiglia S, Martín-Tereso J, Ter Wijlen H (2008) In vitro evaluation of effects of ten essential oils at three doses on ruminal fermentation of high concentrate feedlot-type diets. Animal Feed Science and Technology 145:259-270. doi: 10.1016/j.anifeedsci.2007.05.037.

Chaves AV, Stanford K, Dugan MER., Gibson LL, McAllister TA, Van Herk F, Benchaar C (2008) Effects of cinnamaldehyde, garlic and juniper berry essential oils on rumen fermentation, blood metabolites, growth performance, and carcass characteristics of growing lambs. Livestock Science 117:215-224. doi: 10.1016/j.livsci.2007.12.013.

Cobellis G, Acuti G, Forte C, Menghini L, De Vincenzi S, Orrú, M., Valiani, A., Pacetti, D., Trabalza-Marinucci, M., 2015. Use of Rosmarinus officinalis in sheep diet formulations: Effects on ruminal fermentation, microbial numbers and in situ degradability. Small Ruminant Research 126:10-18. doi: 10.1016/j.smallrumres.2015.01.018.

Cobellis G, Trabalza-Marinucci M, Marcotullio MC, Yu Z, (2016a) Evaluation of different essential oils in modulating methane and ammonia production, rumen fermentation, and rumen bacteria in vitro. Animal Feed Science and Technology 215:25-36. doi: 10.1016/j.anifeedsci.2016.02.008.

Cobellis G., Trabalza-Marinucci M, Yu Z (2016b) Critical evaluation of essential oils as rumen modifiers in ruminant nutrition: A review. Science of the Total Environment 545-546: 556-568. doi: 10.1016/j.scitotenv.2015.12.103.

Cochran WG, William G, Cox GM (1992) Experimental designs. Wiley.

De Rosa M, Gambacorta A, Gliozzi A (1986) Structure, biosynthesis, and physicochemical properties of archaebacterial lipids. Microbiological Reviews 50:70-80.

Dey A, Paul SS, Lailer PC, Dahiya SS (2021) Reducing enteric methane production from buffalo (Bubalus bubalis) by garlic oil supplementation in in vitro rumen fermentation system. SN Applied Sciences 3:187. doi: 10.1007/s42452-021-04264-6.

Diario Oficial de la Federación (2001) Norma oficial mexicana NOM-062ZOO-1999 Especificaciones técnicas para la producción, cuidado y uso de los animales de laboratorio. CDMX. Available at: https://www.gob.mx/cms/uploads/attachment/file/203498/NOM-062ZOO-1999_220801.pdf

Doreau M, Arturo-Schaan M, Laverroux S (2017) Garlic oil reduces ruminal fatty acid biohydrogenation in vitro. European Journal of Lipid Science and Technology 119:1-21. doi: 10.1002/ejlt.201500388.

European parliament (2003) Regulation (ec) no 1831/2003 of the european parliament and of the council of 22 september 2003 on additives for use in animal nutrition (Text with EEA relevance). Official Journal of the European Union 268:29-43.

FAO (2016) El estado mundial de la agricultura y la alimentación 2016: Cambio climático, agricultura y seguridad alimentaria. 49-75. 
Ferme D, Banjac M, Calsamiglia S, Busquet M, Kamel C, Avgustin G (2004) The effects of plant extracts on microbial community structure in a rumensimulating continuous-culture system as revealed by molecular profiling. Folia Microbiologica. 49:151-165.

Fernández-Agulló A, Freire MS, González-Álvarez J (2015) Effect of the extraction technique on the recovery of bioactive compounds from eucalyptus (Eucalyptus globulus) wood industrial wastes. Industrial Crops and Products 64:105-113. . doi: 10.1016/j.indcrop.2014.11.031.

Fondevila M, Pérez-Espés B (2008) A new in vitro system to study the effect of liquid phase turnover and $\mathrm{pH}$ on microbial fermentation of concentrate diets for ruminants. Animal Feed Science and Technology 144:196-211. doi: 10.1016/j.anifeedsci.2007.10.013.

Foskolos A, Siurana A, Rodriquez-Prado M, Ferret A, Bravo D, Calsamiglia S (2015) The effects of a garlic oil chemical compound, propyl-propane thiosulfonate, on ruminal fermentation and fatty acid outflow in a dual-flow continuous culture system. Journal of Dairy Science 98:5482-5491. doi: 10.3168/jds.2014-8674.

France J, Dhanoa MS, Theodorou MK, Lister SJ, Davies DR, Isac D, Williams BA, Dhanoa MS, Mcallan AB, France J (1993) A model to interpret gas accumulation profiles associated with in vitro degradation of ruminant feeds. Journal of Theoretical Biology 163:99-111. doi: 10.1006/jtbi.1993.1109.

García-González R, López S, Fernández M, Bodas R, González JS (2008) Screening the activity of plants and spices for decreasing ruminal methane production in vitro. Animal Feed Science and Technology 147:36-52. doi: 10.1016/J.ANIFEEDSCI.2007.09.008.

Gerber PJ, Steinfeld H, Henderson B, Mottet A, Opio C, Dijkman J, Falcucci A, Tempio, G (2013) Tackling climate change through livestock - A global assessment of emissions and mitigation opportunities, Food and Agriculture Organization of the United Nations 14:12-16.

Getachew, G., Makkar, H.P.S., Becker, K., 2002. Tropical browses: contents of phenolic compound and stoichiometric relationship between short chain fatty acid and in vitro gas production. J Agr Sci Camb 139:341-352. doi: 10.1017/S0021859602002393.

Getachew G, Robinson PH, DePeters EJ, Taylor SJ (2004) Relationships between chemical composition, dry matter degradation and in vitro gas production of several ruminant feeds. Animal Feed Science Technology 111:57-71. doi: 10.1016/S0377-8401(03)00217-7.

Gopu CL, Aher S, Mehta H, Paradkar AR, Mahadik KR (2008) Simultaneous determination of cinnamaldehyde, eugenol and piperine by HPTLC densitometric method. Phytochemicl Analysis 19:116-121. doi: 10.1002/pca.1022.

Grant RH, Mertens DR (1992) Influence of buffer ph and raw corn starch addition on in vitro fiber digestion kinetics. Journal of Dairy Science 75:27622768. doi: 10.3168/jds.S0022-0302(92)78039-4.

Griffin SG, Wyllie SG, Markham JL, Leach DN (1999) The role of structure and molecular properties of terpenoids in determining their antimicrobial activity. Flavour and Fragrance Journal 14:322-332.

Hart KJ, Yáñez-Ruiz DR, Duval SM, McEwan NR, Newbold CJ (2008) Plant extracts to manipulate rumen fermentation. Animal Feed Science and Technology 147:8-35. doi: 10.1016/j.anifeedsci.2007.09.007.

Hiltner P, Dehority BA (1983) Effect of soluble carbohydrates on digestion of cellulose by pure cultures of rumen bacteria. Applied and Environmental Microbiology 46:642-648.

Hoover WH (1986) Chemical factors involved in ruminal fiber digestion. Journal of Dairy Science 69:2755-2766.

Intergovernmental Panel on Climate Change IPCC (2014a) Climate change. Mitigation of climate change: 150-211. doi: 10.1017/CBO9781107415416.

Intergovernmental Panel on Climate Change IPCC (2014b) Informe de síntesis. contribución de los grupos de trabajo I, II y III al quinto informe de evaluación del grupo intergubernamental de expertos sobre el cambio climático: 170-200.

Jafari S, Goh YM, Rajion MA, Faseleh Jahromi M, Ebrahimi M (2016) Ruminal methanogenesis and biohydrogenation reduction potential of papaya (Carica papaya) leaf: an in vitro study. Italian Journal of Animal Science

\section{5:157-165. doi: 10.1080/1828051X.2016.1141031.}

Jahani-Azizabadi H, Mesgaran MD, Vakili AR, Rezayazdi K, Hashemi M (2011) Effect of various medicinal plant essential oils obtained from semi-arid climate on rumen fermentation characteristics of a high forage diet using in vitro batch culture. African Journal of Microbiology Research 5:4812-4819. doi: $10.5897 /$ ajmr11.575.

Jiang Y, Wu N, Fu YJ, Wang W, Luo M, Zhao CJ, Zu YG, Liu XL (2011) Chemical composition and antimicrobial activity of the essential oil of Rosemary. Environmental Toxicology and Pharmacology 32:63-68. doi: 10.1016/j.etap.2011.03.011.

Joch M, Kudrna V, Hučko B (2017) Effects of geraniol and camphene on in vitro rumen fermentation and methane production. Scientia Agriculturae Bohemica 48:63-69. doi: 10.1515/sab-2017-0012.

Kamel C, Greathead HMR, Tejido ML, Ranilla MJ, Carro MD (2008) Effects of allicin and diallyl disulfide on in vitro rumen fermentation of a mixed diet. Animal Feed Science Technology 145:351-363.

Kamel C, Greathead MJ, Ranilla ML, Tejido S, Ramos M, Carro D (2009) Effects of garlic oil on in vitro rumen fermentation and methane production are influenced by the basal diet. Dairy Cattle: 110-15. Available at: https://en.engormix.com/dairy-cattle/forums/forum-effects-garlic-oilt28442/

Kobayashi Y (2010) Abatement of methane production from ruminants: trends in the manipulation of rumen fermentation. Asian-Australasian Journal of Animal Sciences 23:410-416. doi: 10.5713/ajas.2010.r.01.

Lawson LD, Gardner CD (2005) Composition, stability, and bioavailability of garlic products used in a clinical trial. Journal of Agricultural and Food Chemistry 53:6254-6261. doi: 10.1021/jf050536+

Macheboeuf D, Morgavi DP, Papon Y, Mousset JL, Arturo-Schaan M (2008) Dose-response effects of essential oils on in vitro fermentation activity of the rumen microbial population. Animal Feed Science and Technology 145:335350. doi: 10.1016/j.anifeedsci.2007.05.044.

Mateos I, Ranilla MJ, Tejido ML, Saro C, Kamel C, Carro MD (2013) The influence of diet type (dairy versus intensive fattening) on the effectiveness of garlic oil and cinnamaldehyde to manipulate in vitro ruminal fermentation and methane production. Animal Production Science 53:299 -307. doi: 10.1071/AN12167.

Menke KH, Raab L, Steingass H (1979) The estimation of the digestibility and metabolizable content of ruminant feedingstudds from the gas production when they are incubated with rumen liquor in vitro. Journal of Agricultural Science 93:217-222.

Meyer NF, Erickson GE, Klopfenstein TJ, Greenquist MA, Luebbe MK, Williams P, Engstrom MA (2009) Effect of essential oils, tylosin, and monensin on finishing steer performance, carcass characteristics, liver abscesses, ruminal fermentation, and digestibility. Journal of Animal Science 87:2346-2354. doi: 10.2527/JAS.2008-1493.

National Research Council (U.S.). Subcommittee on Dairy Cattle Nutrition (2001) Nutrient Requirements of Dairy Cattle. National Academies Press.

O'Grady MN, Maher M, Troy DJ, Moloney AP, Kerry JP (2006) An assessment of dietary supplementation with tea catechins and rosemary extract on the quality of fresh beef. Meat Science 73:132-143.

O'Mara FP (2011) The significance of livestock as a contributor to global greenhouse gas emissions today and in the near future. Animal Feed Science and Technology 166-167:7-15. doi: 10.1016/J.ANIFEEDSCI.2011.04.074.

Ørskov E (1994) Recent advances in understanding of microbial transformation in ruminants. Livestock Production Science 39:53-60. doi: 10.1016/0301-6226(94)90153-8.

Patra AK (2012) Dietary phytochemicals and microbes. Springer.

Patra AK, Kamra DN, Agarwal N (2009) Effects of extracts of spices on rumen methanogenesis, enzyme activities and fermentation of feeds in vitro. JJournal of the Science of Food and Agriculture 90:511-520. doi: 10.1002/jsfa.3849.

Patra AK, Kamra DN, Agarwal N (2006a) Effect of plant extracts on in vitro methanogenesis, enzyme activities and fermentation of feed in rumen liquor of buffalo. Animal Feed Science and Technology 128:276-291. doi: 


\subsection{6/j.anifeedsci.2005.11.001}

Patra AK, Kamra DN, Agarwal N (2006b) Effect of spices on rumen fermentation, methanogenesis and protozoa counts in in vitro gas production test. International Congress Series 1293:176-179. doi: 10.1016/j.ics.2006.01.025.

Patra AK, Saxena J (2009) Dietary phytochemicals as rumen modifiers: A review of the effects on microbial populations. Antonie van Leeuwenhoek, International Journal of General and Molecular Microbiology 96:363-375. doi: 10.1007/s10482-009-9364-1.

Patra, Amlan K, Saxena, J. (2010). A new perspective on the use of plant secondary metabolites to inhibit methanogenesis in the rumen. In Phytochemistry (Vol. 71, Issues 11-12, pp. 1198-1222). Elsevier Ltd. https://doi.org/10.1016/j.phytochem.2010.05.010

Patra AK, Yu Z (2015) Effects of adaptation of in vitro rumen culture to garlic oil, nitrate, and saponin and their combinations on methanogenesis, fermentation, and abundances and diversity of microbial populations. Frontiers in Microbiology 6:1-11. doi: 10.3389/fmicb.2015.01434.

Patra AK, Yu Z (2012a) Effects of essential oils on methane production and fermentation by, and abundance and diversity of, rumen microbial populations. Applied and Environmental Microbiology 78:4271-4280. doi: 10.1128/AEM.00309-12.

Poornachandra KT, Malik PK, Dhali A, Kolte AP, Bhatta R (2019) Effect of combined supplementation of tamarind seed husk and soapnut on enteric methane emission in crossbred cattle. Carbon Management: 1-11. doi: 10.1080/17583004.2019.1640136.

Righi F, Simoni M, Foskolos A, Beretti V, Sabbioni A, Quarantelli A (2017) In vitro ruminal dry matter and neutral detergent fibre digestibility of common feedstuffs as affected by the addition of essential oils and their active compounds. Journal Animal Feed Science 26:204-212. doi: 10.22358/jafs/76754/2017.

Roy D, Tomar SK, Sirohi SK, Kumar V, Kumar M (2014) Efficacy of different essential oils in modulating rumen fermentation in vitro using buffalo rumen liquor. Veterinary World 7:213-218. doi: 10.14202/vetworld.2014.213-218.

Sahli F, Darej C, Moujahed N (2018) Potential of white garlic powder (Allium sativum $\mathrm{L}$.) to modify in vitro ruminal fermentation. South African Journal of Animal Sciences 48 253-260. doi: 10.4314/SAJAS.V4812.6.

Salem AZM (2012) Oral administration of leaf extracts to rumen liquid donor lambs modifies in vitro gas production of other tree leaves. Animal Feed Science and Technology 176: 94-101. doi: 10.1016/j.anifeedsci.2012.07.011.

Salzer UJ, Furia TE (1977) The Analysis of Essential Oils and Extracts (Oleoresins) from Seasonings - A Critical Review. Critical Reviews in Food Science and Nutrition 9:345-373. doi: 10.1080/10408397709527239.
Sharma V, McNeill JH (2009) To scale or not to scale: The principles of dose extrapolation. British Journal of Pharmacology 157:907-921. doi: 10.1111/j.1476-5381.2009.00267.x.

Sirohi SK, Pandey N, Goel N, Singh B, Mohini M, Pandey P, Chaudhry PP (2009) Microbial activity and ruminal methanogenesis as affected by plant secondary metabolites in different plant extracts. Environmental Engineering 1:52-58.

Theodorou MK, Williams BA, Dhanoa MS, McAllan AB, France J (1994) A simple gas production method using a pressure transducer to determine the fermentation kinetics of ruminant feeds. Animal Feed Science and Technology 48:185-197. doi: 10.1016/0377-8401(94)90171-6.

Tocmo R, Wu Y, Liang D, Fogliano V, Huang D (2016) Boiling enriches the linear polysulfides and the hydrogen sulfide-releasing activity of garlic. Food Chemistry 221:1867-1873. doi: 10.1016/j.foodchem.2016.10.076.

Torres-Salado N, Sánchez-Santillán P, Rojas-García AR, Herrera-Pérez J, Hernández-Morales J (2017) Producción de gases efecto invernadero in vitro de leguminosas arbóreas del trópico seco mexicano. Archivos de Zootecnia 67:55-59. doi: 10.21071/az.v67i257.3491.

Ultee A, Bennik MHJ, Moezelaar R (2002) The phenolic hydroxyl group of carvacrol is essential for action against the food-borne pathogen Bacillus cereus. Applied and Environmental Microbiology 68:1561-1568. doi: 10.1128/AEM.68.4.1561-1568.2002.

Ungerfeld EM (2018) Inhibition of rumen methanogenesis and ruminant productivity: A meta-analysis. Frontiers in Veterinary Science 5:1-13. doi: 10.3389/fvets.2018.00113.

Van Soest PJ, Robertson JB, Lewis BA (1991) Methods for Dietary Fiber, Neutral Detergent Fiber, and Nonstarch Polysaccharides in Relation to Animal Nutrition. Journal of Dairy Science 74:3583-3597. doi: 10.3168/jds.S0022-0302(91)78551-2.

Wencelová M, Váradyová Z, Mihaliková K, Čobanová K, Plachá I, Pristaš $P$, Jalč $D$, Kišidayová $S$ (2015) Rumen fermentation pattern, lipid metabolism and the microbial community of sheep fed a high-concentrate diet supplemented with a mix of medicinal plants. Small Ruminant Research 125:64-72. doi: 10.1016/j.smallrumres.2015.01.028.

Williams WL, Tedeschi LO, Kononoff PJ, Callaway TR, Dowd SE, Karges K, Gibson ML (2010) Evaluation of in vitro gas production and rumen bacterial populations fermenting corn milling (co)products. Jornual of Dairy Science 93:4735-4743. doi: 10.3168/jds.2009-2920.

Yang WZ, Benchaar C, Ametaj BN, Chaves AV, He ML, McAllister TA (2007) Effects of garlic and juniper berry essential oils on ruminal fermentation and on the site and extent of digestion in lactating cows. Journal of Dairy Science 90:5671-5681. doi: 10.3168/jds.2007-0369. 